\title{
ANÁLISE MORFOLÓGICA DAS FORMAS IMATURAS DE SARCONESIA CHLOROGASTER (WIEDEMANN), (DIPTERA, CALLIPHORIDAE, TOXOTARSINAE)
}

\author{
Sionei Ricardo Bonatto ${ }^{2}$ \\ Claudio José Barros de Carvalho ${ }^{2}$
}

\begin{abstract}
Morphological anAlysis of imMATURE STAGES OF SARCONESIA CHLOrogaster (Wiedemann) (Diptera, Calliphoridae, Toxotarsinae). Morphological characteristics of the immature of Sarconesia chlorogaster (Wiedemann, 1830) were obtained rearing it on an artificial diet in a temperature controlled chamber set at $27 \pm 1^{\circ} \mathrm{C}, 70 \pm 10 \% \mathrm{RH}$ and 12 hours photophase. The egg, three larval instars and puparium were described and illustrated together with the larval cephalopharyngeal skeleton. Some characters were studied, for the first time using the scanning electron microscopy.

KEY WORDS. Diptera, Calliphoridae, Sarconesia chlorogaster, morphology, immature stages
\end{abstract}

Toxotarsinae é um pequeno grupo endêmico da calíforofauna Neotropical, no qual situa-se Sarconesia chlorogaster (Wiedemann, 1830). A distribuição geográfica das espécies de Toxotarsinae limita-se à regiões de clima frio, sendo que as espécies que ocorrem em baixas latitudes (e.g. Bolívia e Peru), são encontradas somente acima de 4200m (DEAR 1979; GREENBERG \& SZYSKA 1984).

Sarconesia chlorogaster possui distribuição exclusivamente sulamericana, entre $10^{\circ}$ e $40^{\circ} \mathrm{S}$, com registros para o Brasil, Argentina, Uruguai, Bolívia, Peru, Chile, Ilhas Juan Fernandez e Ilhas da Páscoa. Esta é a única espécie de Toxotarsinae que ocorre no Brasil, onde sua distribuição está limitada aos estados da Região Sul do país (MELLO 1972; DEAR 1979; LOPES \& AlBUQUERQUE 1982; BAUMGARTNER \& GREENBERG 1985; QUEIROZ et al. 1985).

O presente estudo tem como justificativa principal a pouca especificidade de estudos anteriores sobre aspectos morfológicos, principalmente das formas imaturas, de S. chlorogaster. Deste modo, são desconhecidos caracteres que possam vir a ajudar o entendendimento da sistemática deste grupo (MARILUIS \& PERIS 1984).

1) Contribuição número 941 do Departamento de Zoologia, Universidade Federal do Paraná.

2) Departamento de Zoologia, Universidade Federal do Paraná, Caixa Postal 19020, 81531-990 Curitiba, Paraná, Brasil. Bolsista do CNPq.

E-mail: srbona@bio.ufpr.br ou cjbcarva@bio.ufpr.br 


\section{MATERIAL E MÉTODOS}

Os espécimens adultos foram coletados na região de Curitiba, próximo ao Departamento de Zoologia da Universidade Federal do Paraná, com armadilhas para moscas descritas por FERREIRA (1978). Como isca foi utilizado peixe com 24 horas de decomposicão, pois Sarconesia chlorogaster é um dos Calliphoridae mais freqüentes neste tipo de isca (FERREIRA 1978; BAUMGARTNER \& GREENBERG 1985).

Os estoques de adultos foram matidos em gaiolas sob condições ambientais e as posturas provenientes destes estoques foram acondicionadas em câmara climatizada, modelo Fanen CDG 347, em tubos plásticos contendo dieta artificial oligídica, seguindo metodologia descrita por BONATTO (1996).

\section{ANÁLISE MORFOLÓGICA}

Para a análise morfológica procedeu-se a criação de 300 larvas, sob as mesmas condições laboratoriais.

Foram fixadas amostras de ovos diretamente em solução de etanol a $80 \%$, após terem sido separados em $\mathrm{NaHSO}_{3}$ e lavados em água destilada.

As larvas destinadas ao estudo morfológico foram sacrificadas em água destilada aquecida à aproximadamente $70-80^{\circ} \mathrm{C}$, durante cinco minutos e transferidas para frascos devidamente etiquetados, contendo solução de álcool etílico à $70 \%$ (SKIDMORE 1985).

Os pupários foram fixados diretamente em álcool etílico a 70\%.

Quando encontradas exúvias de primeiro e segundo ínstares no meio de cultura, estas eram acondicionadas em frascos devidamente etiquetados, contendo solução de álcool etílico à $70 \%$.

$\mathrm{Na}$ descrição das larvas, esqueletos céfalo-faríngeos e pupários, foi utilizada a terminologia adotada por FERRAR (1987) e SHEWELL (1987).

\section{MENSURAÇõES}

As mensurações foram realizadas a partir da observação de 30 exemplares de cada ínstar, com auxílio de microscópio estereoscópico Wild M5, com ocular micrométrica acoplada.

\section{Desenhos}

Os desenhos foram elaborados com auxílio de microscópio esteroscópico Wild M5, com lente duplicadora e câmara clara acopladas.

As larvas dos três ínstares foram clarificadas em solução de $\mathrm{KOH}(10 \%)$ durante 24 horas, para estudo do esqueleto céfalo-faringeo, das bandas e dos tipos de espinhos e dos espiráculos anteriores e posteriores.

Os esqueletos céfalo-faríngeos de larvas de primeiro, segundo e terceiro ínstares foram retirados das exúvias com auxílio de estiletes de ponta fina e pincel, imersos em solução de álcool e glicerina (9:1), comparados quanto a posição e constituição originais nas larvas clarificadas e desenhados. Os esqueletos céfalo-faríngeos de terceiro ínstar, foram dissecados de larvas na fase pós-alimentar.

Detalhes da morfologia das formas imaturas foram indicadas somente nas figuras referentes ao ovo, larva de terceiro ínstar e pupário. 


\section{MICROSCOPIA ELETRÔNICA DE VARREDURA}

A preparação do material para observações em elétron-microscópio de varredura, modelo Philips SEM-505, foi realizada no Centro de Microscopia Eletrônica da Universidade Federal do Paraná.

Os ovos e larvas de primeiro, segundo e terceiro ínstares foram sacrificadas em água a $70-80^{\circ} \mathrm{C}$ e fixadas em solução de etanol a $70 \%$. Posteriormente este material era levado a um equipamento de ultra-som, para retirada de possíveis sedimentos incrustados sobre o tegumento, durante três a cinco minutos. Em seguida procedia-se a desidratação do material, através da passagem deste por uma série alcoólica crescente $(80 \%, 85 \%, 90 \%, 95 \%$ e absoluto), durante 30 minutos em cada concentração. Depois o material era depositado em pequenos recipientes telados, os quais permaneciam imersos em etanol absoluto, no interior de uma placa de Petri. Estes recipientes eram então acondicionados em aparelho desidratador, modelo Balzers CPD-010, até o material atingir o ponto crítico e em seguida colado em suportes para o SEM-505, com cola de grafite. Tão logo a cola secasse, o material era acondicionado em aparelho metalizador, modelo Balzers SCD-030, para a deposição de uma camada de ouro, com aproximadamente $200 \AA$ de espessura, sobre a superfície das peças.

Os pupários eram fixados diretamente em etanol (70\%) e após a passagem pelo ultra-som, eram depositados em placa de Petri e desidratados em estufa a $70^{\circ} \mathrm{C}$, durante 48 horas. Posteriormente procedia-se a colagem nos suportes para o SEM505 e a metalização com ouro, a exemplo dos ovos e larvas.

Após o preparo, o material era observado e fotografado em SEM-505, ou acondicionado em câmara de vácuo para posterior análise.

\section{RESULTADOS E DISCUSSÃO}

\section{ASPECTOS MORFOLÓGICOS DAS FORMAS IMATURAS}

Ovo (Fig. 1)

Comprimento médio $1,27 \pm 0,04 \mathrm{~mm}$, largura média $0,31 \pm 0,02 \mathrm{~mm}$.

Coloração geral branco leitosa.

Descrição. Alongados de forma cilíndrica, com a superfície ventral ligeiramente convexa (Fig. 1B). Metade anterior pouco mais estreita que a posterior. Cório totalmente recoberto por uma fina reticulação superficial - padrão geométrico de difícil observação em microscopia óptica - e translúcido, permitindo visualizar o embrião em seu interior. Micrópila simples, situada na porção apical anterior (Fig. 1C). Superficie dorsal com uma linha de eclosão caracterizada por uma disjunção do cório, iniciando-se na região micropilar onde é mais larga e delgada, por onde inicia-se a eclosão, extendendo-se até o terço posterior (Fig. 1A).

\section{Larva de primeiro instar (Fig. 2)}

Comprimento médio total $3,54 \pm 0,03 \mathrm{~mm}$, incluindo a região cefálica.

Coloração geral. Cutícula translúcida, porém, as estruturas internas fornecem à larva uma coloração branca leitosa. 

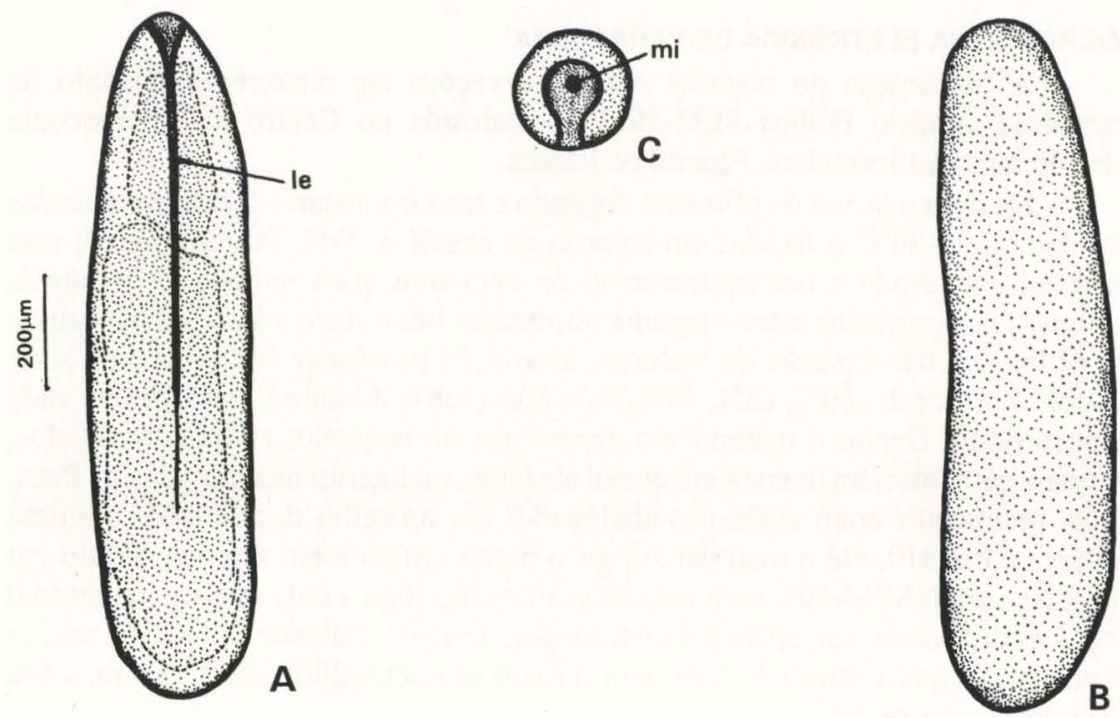

Fig. 1. Ovo de Sarconesia chlorogaster. (A) Vista dorsal; (B) vista lateral; (C) vista frontal da região micropilar. (le) Linha de eclosão, (mi) micrópila.

Descrição. Larva típica de Cyclorrhapha. Cilíndrica, com a região anterior mais afilada que a posterior. O corpo compreende 12 segmentos: cabeça, três segmentos torácicos, seguidos de oito segmentos abdominais. Aspecto geral figura 2A-C.

Cabeça (Fig. 2D). Pouco desenvolvida e praticamente indivisa com o segmento protorácico; dividida por um sulco longitudinal em dois lobos cefálicos. Estruturas sensoriais pouco desenvolvidas e conseqüentemente de difícil visualização ao estereomicroscópio. Região ventral com abertura do canal alimentar, com vários sulcos ramificados, melhor caracterizados a partir do segundo ínstar.

Esqueleto céfalo-faríngeo (Fig. 2E-F). De tamanho reduzido, formado por poucos escleritos, fracamente esclerotinizados. Ganchos orais pares, reduzidos a pequeno esclerito em forma de gancho, um esquerdo e outro direito, não articulados com os demais escleritos. Esclerito oral acessório aparentemente ausente. Pequenos escleritos dentais situados na base dos ganchos orais. Esclerito intermediário delgado, em forma de barra triangular quando visto de perfil (Fig. 2E), e em forma de "H", quando visto ventralmente (Fig. 2F); com prolongamentos laterais do esclerito faríngeo, que o ultrapassam anteriormente. Arco dorsal presente, unindo os cornos dorsais esquerdo e direito do esclerito faringeo. Esclerito faríngeo bem desenvolvido, em relação aos demais escleritos; barra parastomal não desenvolvida; corno dorsal pouco menor que o ventral, ambos delgados e terminando em ponta afilada. Ventralmente os cornos ventrais são unidos por uma fina membrana não esclerotinizada.

Bandas de espinhos segmentares (Fig. 2A-C). Formadas por espinhos fraca- 

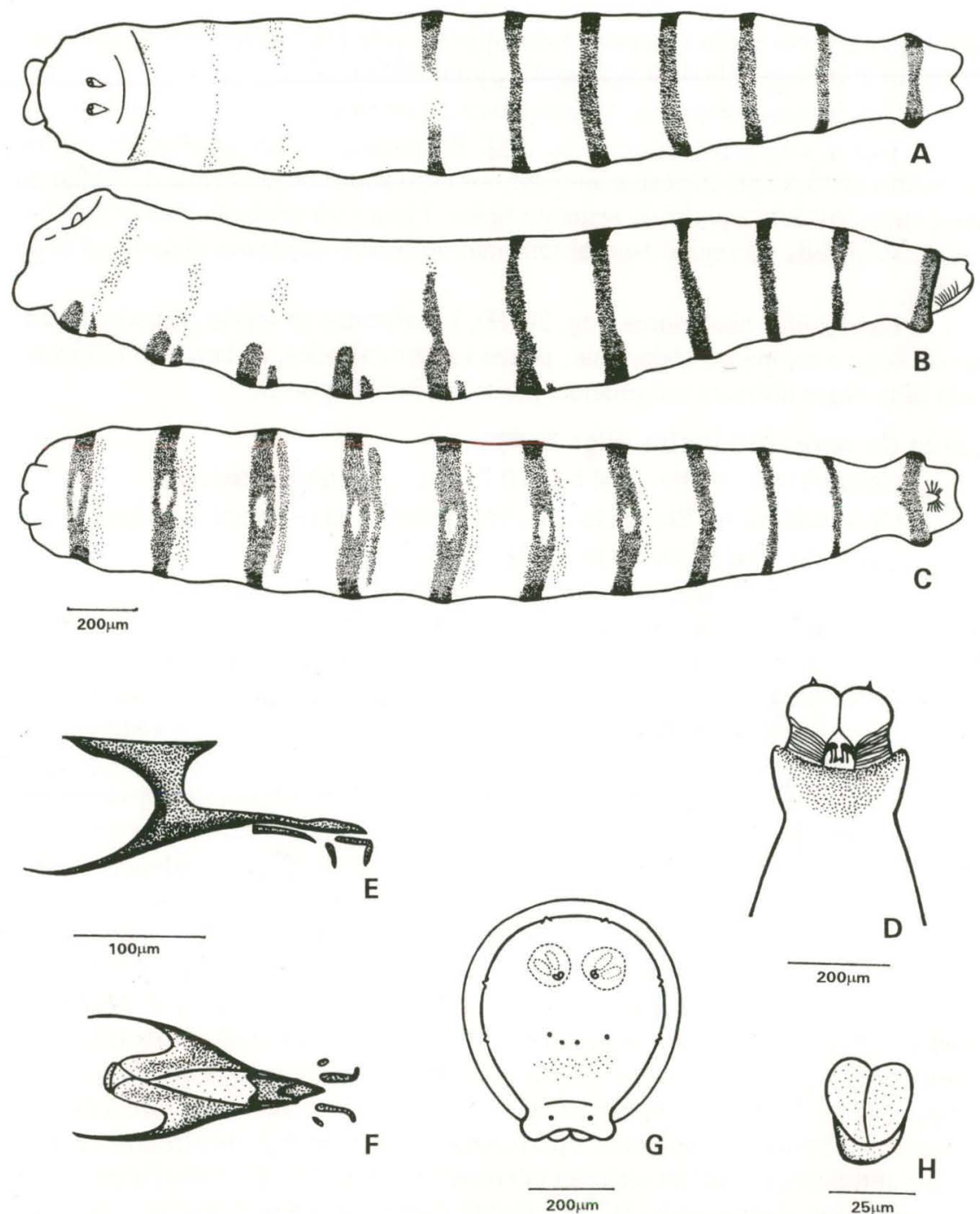

Fig. 2. Larva de primeiro instar de Sarconesia chlorogaster. (A) Vista dorsal; (B) vista lateral; (C) vista ventral; (D) detalhe da região anterior, vista ventral; $(E)$ esqueleto céfalo-faringeo, vista lateral; $(F)$ esqueleto céfalo-faringeo, vista ventral; $(G)$ detalhe da região posterior, vista frontal; $(\mathrm{H})$ espiráculo posterior.

mente esclerotinizados, de forma simples, quando observados em microscopia óptica, e sempre orientados para trás. Bandas iniciando no primeiro segmento torácico, repetindo-se na região anterior de cada segmento; completas até o quarto segmento abdominal, no qual pode haver uma aparente descontinuidade dorsal, devido a espinhos pouco esclerotinizados; demais segmentos somente com banda de espinhos ventrais. Mais desenvolvidas na região ventral onde, nos segmentos 
abdominais, pode ocorrer formação de espinhos paralela à banda principal, representando a formação de duas bandas de espinhos (Fig. 2C).

Espiráculos anteriores. Aparentemente ausentes.

Tubérculos e processos (Fig. $2 \mathrm{G}$ ). Restritos à região terminal do último segmento abdominal, dispostos ao redor dos espiráculos posteriores e da região do ânus, mais visíveis a partir do segundo ínstar. Placa anal bilobada, pouco pronunciada, localizada na região ventral terminal do oitavo segmento abdominal (Fig. 2C,G).

Espiráculos posteriores (Fig. 2G,H). Localizados na região posterior terminal do oitavo segmento abdominal; pouco esclerotinizados, de tamanho reduzido, com uma única abertura estigmática; peritrema indistingüível.

\section{Larva de segundo instar (Figs 3,4 )}

Comprimento médio total $8,13 \pm 0,74 \mathrm{~mm}$, incluindo a cabeça.

Coloração geral. Branca leitosa, semelhante à larva de primeiro ínstar.

Características. Aspecto geral figura 3A-C.

Cabeça (Fig. 3D). Sulco longitudinal mais proeminente que em larva de primeiro ínstar, realçando os dois lobos cefálicos, cada qual com estruturas sensoriais na extremidade apical, estas mais desenvolvidas do que nas larvas de primeiro ínstar; dorsalmente encontra-se um órgão sensorial dorsal ("antena"), abaixo da qual situa-se um órgão sensorial ventral ("palpo maxilar"). Ventral e centralmente situa-se o canal alimentar, ao redor da qual encontram-se sulcos ramificados, direcionados para o centro. Parte distal dos ganchos orais exteriorizam-se através do canal alimentar. Posteriormente a este canal encontram-se os "palpos labiais".

Esqueleto céfalo-faríngeo (Fig. 3E,F). Semelhante ao de primeiro ínstar, porém, mais esclerotinizado, de tamanho maior e com escleritos mais evidentes. Ganchos orais desenvolvidos, anteriormente bem recurvados, com um orifício de tamanho médio na base; aparentemente sem esclerito oral acessório; escleritos dentais bem visíveis de forma subtriangular. Esclerito intermediário alongado, em forma de "H" quando visto ventralmente (Fig. 3F); anteriormente articulado frouxamente aos ganchos orais, e posteriormente articulado fortemente ao esclerito faríngeo (Fig. 3E); escleritos hipostomais, visíveis ventralmente em forma de duas placas semifundidas basalmente e perfuradas posteriormente, localizadas entre os braços anteriores do "H" do esclerito intermediário (Fig. 3F). Esclerito faríngeo com barra parastomal desenvolvida; arco dorsal ligando os cornos dorsais, estes mais desenvolvidos que os cornos ventrais, terminando em ponta afilada; corno ventral com extremidade posterior larga, com uma "janela fechada" próxima ao apódema dorsal e pouco esclerotinizada, unidos ventralmente por uma membrana translúcida pouco esclerotinizada.

Espiráculos anteriores (Figs 3A-C, 4A). Localizados lateralmente na região posterior do segmento protorácico, semelhantes a dois pequenos sacos com as projeções digitiformes, onde abrem-se as fendas estigmáticas. Número de projeções digitiformes variando entre $7-11$ projeções $(n=30)$, podendo haver variação no número destas projeções tanto no mesmo indivíduo quanto em indivíduos diferentes, porém, o número de projeções neste ínstar se mantém no terceiro ínstar. 

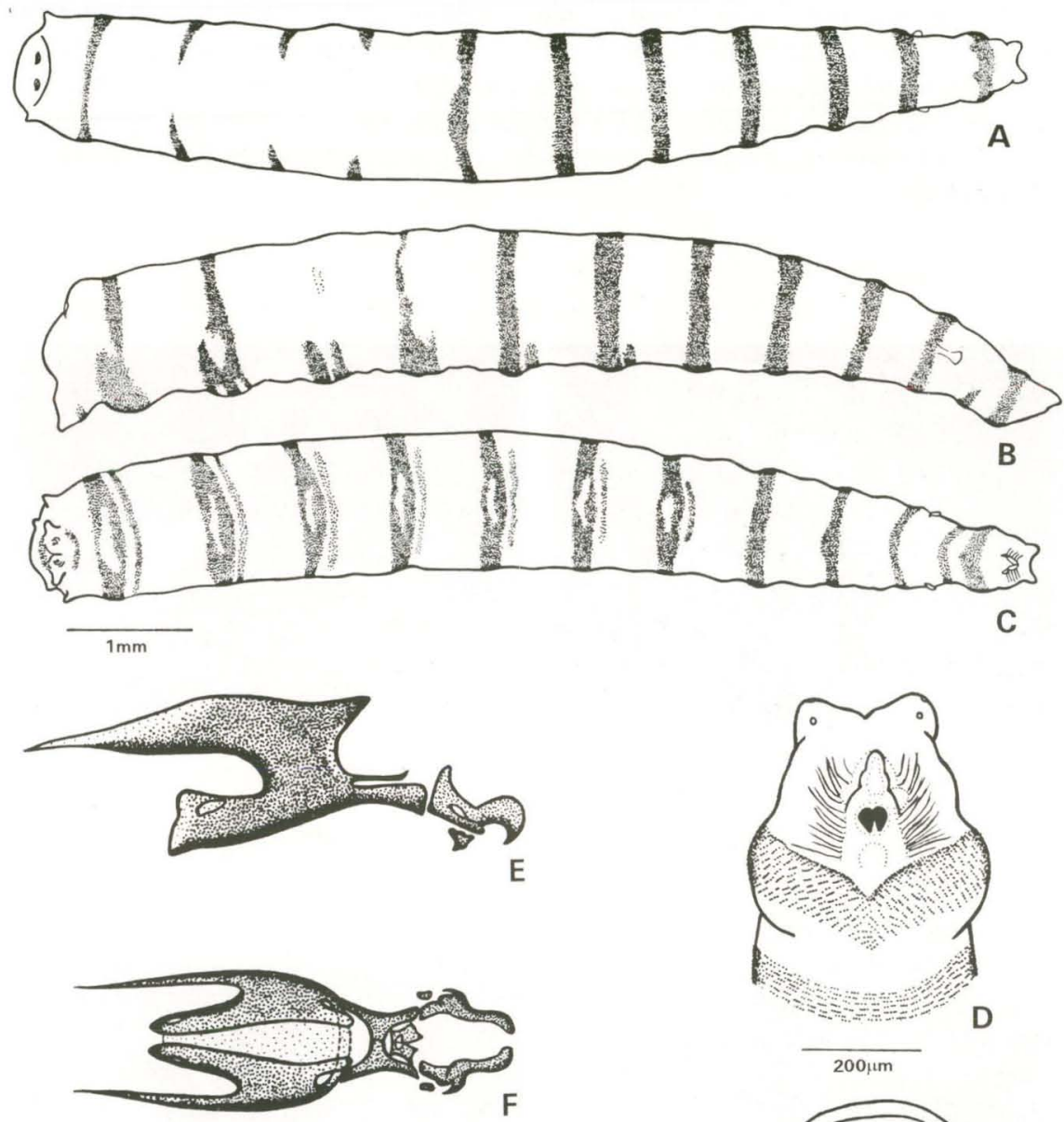

F

$200 \mu m$

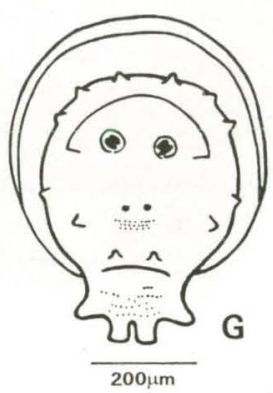

Fig. 3. Larva de segundo instar de Sarconesia chlorogaster. (A) Vista dorsal; (B) vista lateral; (C) vista ventral; (D) detalhe da região anterior, vista ventral; (E) esqueleto céfalo-faringeo, vista lateral; $(F)$ esqueleto céfalo-faríngeo, vista ventral; $(G)$ detalhe da região posterior, vista frontal; $(H)$ espiráculo posterior. 
Bandas de espinhos segmentares (Figs 3A-C, 4B). Mais robustas que nas larvas de primeiro instar, compostas basicamente de espinhos simples, esclerotinizados e de base alargada, dispostos de três a sete fileiras, raramente com mais (Fig. 4B). Segmento protorácico com uma banda extra de espinhos mediana, restrita somente à região ventral (Fig. 3B,C). Bandas de espinhos segmentares completas, com exceção dos segmentos abdominais 5-7, nos quais as bandas são incompletas dorsalmente.

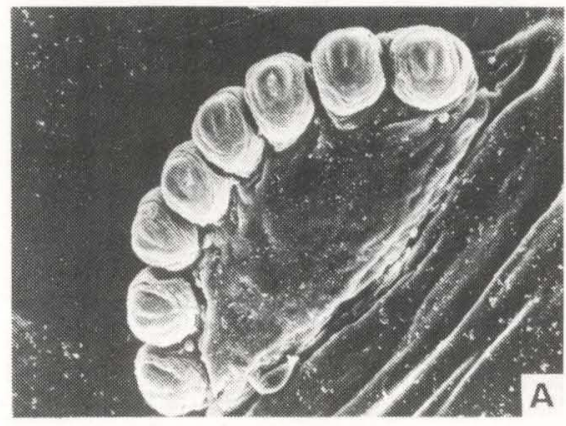

50 um

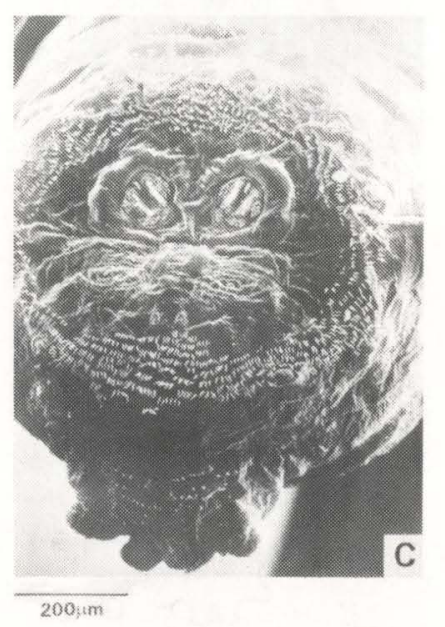

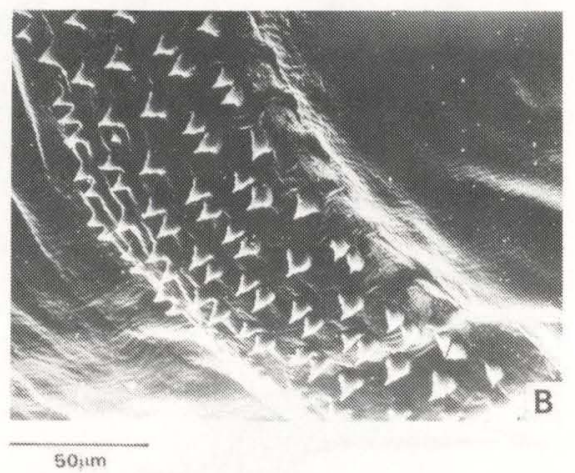

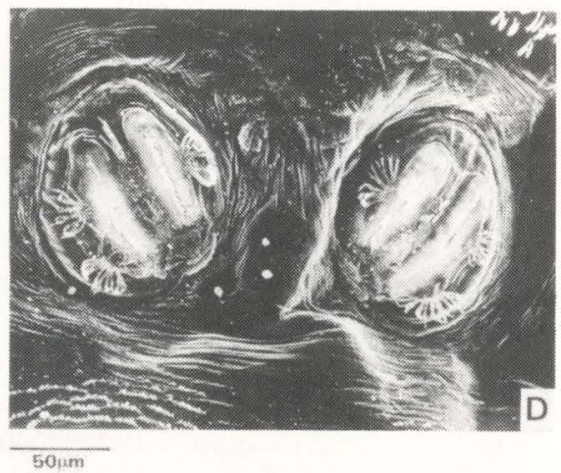

Fig. 4. Fotomicrografia de varredura da larva de segundo instar de Sarconesia chlorogaster. (A) Espiráculo anterior direito; (B) terceira banda de espinhos, vista látero-ventral; (C) detalhe da região posterior, vista frontal; (D) espiráculos posteriores. 
Tubérculos e processos (Figs 3C,G, 4C). Tubérculos do último segmento abdominal pouco proeminentes. Situados ao redor da região espiracular e dispostos simetricamente, podem ser encontrados os tubérculos: dorsais interno, mediano e externo; ventrais externo, mediano e interno (Fig. 3G). Placa anal bilobada e proeminente, circundada de pequenas papilas sensoriais pouco visíveis ao estereomicroscópio (Figs 3C,G, 4C).

Espiráculos posteriores (Figs $3 \mathrm{H}, 4 \mathrm{C}, \mathrm{D}$ ). Mais esclerotinizados que os de primeiro ínstar, com peritrema evidente e incompleto, cada um com duas aberturas estigmáticas, ovais alongadas. Aberturas das glândulas periespiraculares com projeções filamentosas ramificadas como na figura 4D; aberturas estigmáticas externas com duas glândulas periespiraculares e as internas com somente uma; entre as aberturas estigmáticas encontra-se uma placa com a quarta abertura de glândula periespiracular (Fig. 4D). Botão situado inferiormente e visível somente através de microscopia de varredura (Fig. 4D).

\section{Larva de terceiro ínstar (Figs 5-8)}

Comprimento médio total $15,26 \pm 0,39 \mathrm{~mm}$, incluindo a cabeça.

Coloração geral. Branca leitosa a creme (bege claro).

Descrição. Aspecto geral figura 5A-C.

Cabeça (Figs 5D, 6A-E). Semelhante à larva de segundo ínstar, porém os lobos cefálicos são mais pronunciados devido ao sulco longitudinal ser mais profundo (Figs 5D, 6A-C). Estruturas sensoriais da cabeça bem desenvolvidas: órgão dorsal ("antena") formada por três segmentos (Fig. 6D); órgão ventral ("palpo maxilar") formado por várias papilas com estruturas sensoriais (Fig. 6E); base dos lobos cefálicos ventralmente, com duas papilas sensoriais (Fig. 6C). Canal alimentar localizado ventralmente, rodeado por sulcos ramificados, anteriormente externamse as extremidades distais dos ganchos orais do esqueleto céfalo-faríngeo e posteriormente, isto é, na base do canal alimentar situam-se os "palpos labiais" em forma de dois pequenos lobos almofadados (Fig. 6B,C).

Esqueleto céfalo-faríngeo (Figs 5E,F, 6F). Fortemente esclerotinizado. Ganchos orais levemente recurvados anteriormente, com base alargada e com pequeno orifício póstero-basal, fracamente articulados com o esclerito intermediário (Fig. $5 \mathrm{E}$ ); superfície ântero-ventral dos ganchos denticulada (Fig. 6F); esclerito oral acessório ímpar bem evidente, localizado entre os ganchos orais (Fig. 5E,F); escleritos dentais em forma de vírgula, localizados muito próximos à base dos ganchos orais. Esclerito intermediário de forma subtriangular quando visto de perfil e de " $\mathrm{H}$ " quando visto ventralmente, com forte articulação com o esclerito faríngeo (Fig. 5E,F). Escleritos hipostomais semelhantes, em forma e posição, aos do segundo ínstar (Fig. 5F). Esclerito faríngeo semelhante ao de segundo ínstar, porém maior e mais esclerotinizado; cornos dorsais aproximadamente duas vezes maiores que os ventrais, unidos dorsal e anteriormente pelo arco dorsal, terminando em ponta afilada pouco esclerotinizada; barra parastomal bem desenvolvida; cornos ventrais com "janela fechada" e unidos ventralmente por membrana pouco esclerotinizada (Fig. 5E,F). 

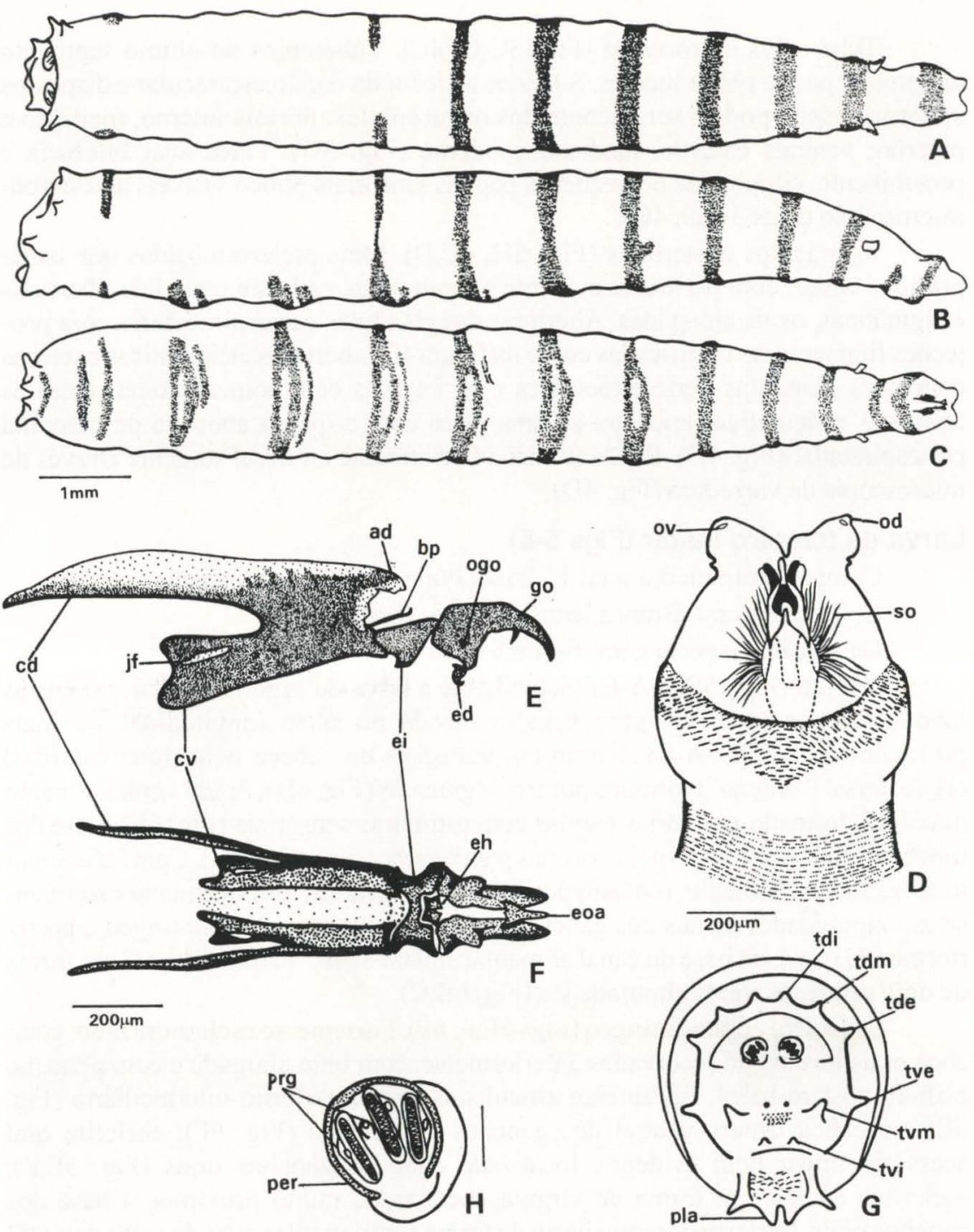

Fig. 5. Larva de terceiro instar de Sarconesia chlorogaster. (A) Vista dorsal; (B) vista lateral; $(C)$ vista ventral; (D) detalhe da região anterior, vista ventral; $(E)$ esqueleto céfalo-faríngeo, vista lateral; (F) esqueleto céfalo-faringeo, vista ventral; $(G)$ detalhe da região posterior, vista frontal; $(\mathrm{H})$ espiráculo posterior. (ad) Arco dorsal, (bp) barra parastomal, (cd) corno dorsal, (cv) corno ventral, (eh) esclerito hipostomal, (ei) esclerito intermediário, (ed) esclerito dental, (eoa) esclerito oral acessório, (jf) janela fechada, (go) gancho oral, (od) órgão dorsal, (ov) órgão ventral, (ogo) orificio do gancho oral, (per) peritrema, (pla) placa anal, (prg) projeção ramificada da glândula periespiracular, (so) sulcos orais ramificados, (tdi) tubérculo dorsal interno, (tdm) tubérculo dorsal mediano, (tde) tubérculo dorsal externo, (tvi) tubérculo ventral interno, (tvm) tubérculo ventral mediano, (tve) tubérculo ventral externo. 


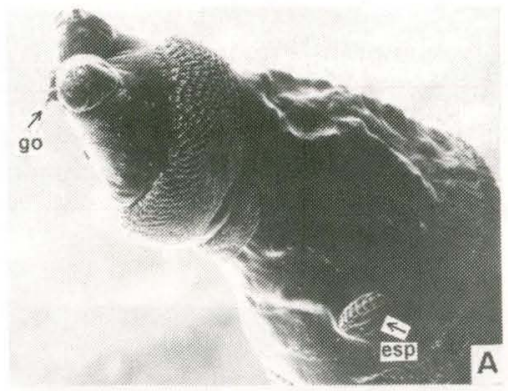

200ium

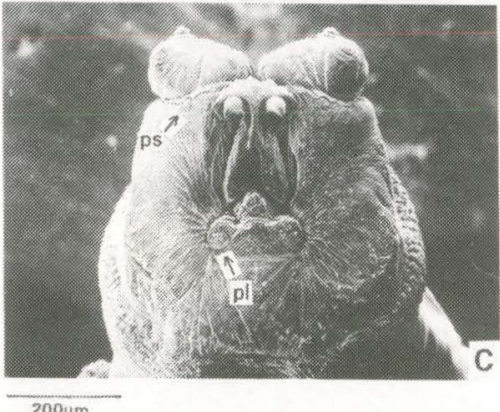

$200 n m$

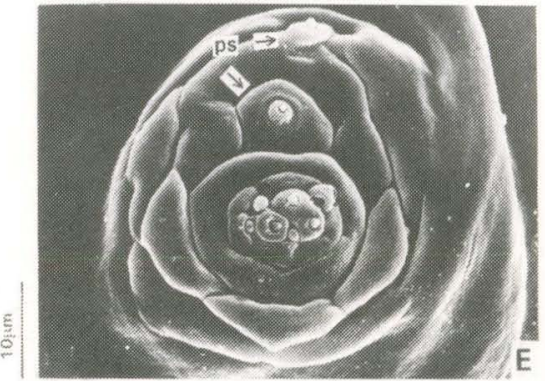

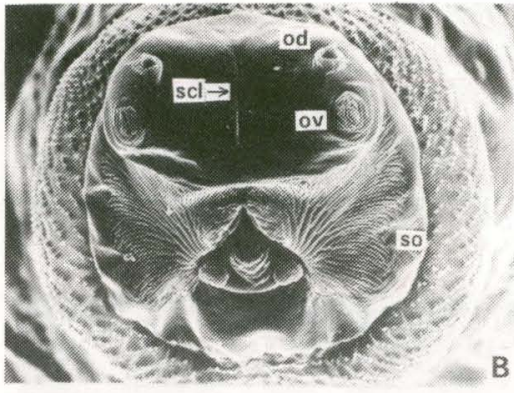

$100 \% 1 \mathrm{~m}$

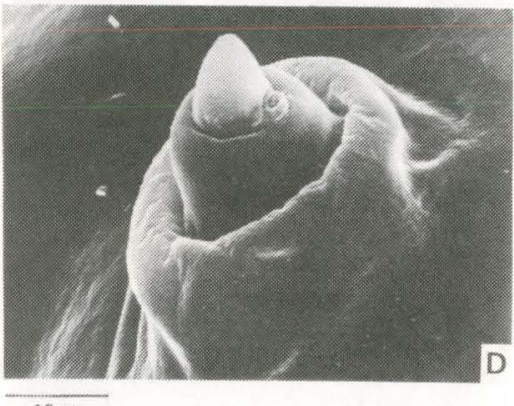

10 : $\mathrm{mm}$

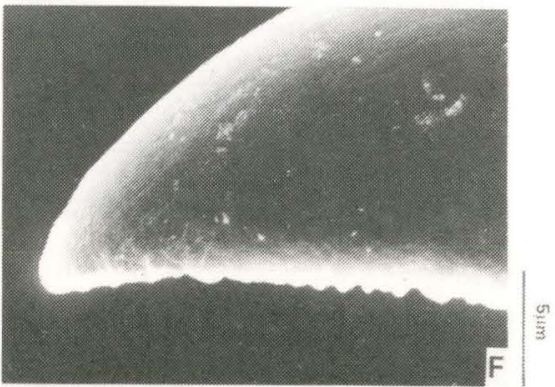

Fig. 6. Fotomicrografia de varredura de larva de terceiro instar de Sarconesia chlorogaster. (A) Região anterior, vista lateral; (B) região anterior, vista frontal; (C) região anterior, vista ventral; (D) órgão dorsal ("antena"); (E) órgão ventral ("palpo maxilar"); (F) detalhe da região anterior do gancho oral, vista lateral. (esp) Espiráculo anterior, (go) gancho oral, (od) órgão dorsal, (ov) órgão ventral, (ps) papila sensorial, (pl) palpo labial, (scl) sulco cefálico longitudinal, (so) sulcos orais ramificados.

Espiráculos anteriores (Figs 5A-C, 6A, 7A-C). Posição e forma como nas larvas de segundo ínstar, porém maiores e mais esclerotinizados (Figs 5A, 6A); número de fendas estigmáticas com a mesma variação encontrada no segundo ínstar (Fig. 7A-C).

Bandas de espinhos segmentares (Figs 5A-C, 7D-F). Tão ou mais robustas e com o mesmo padrão de distribuição que em larvas de segundo ínstar (Fig. 5A-C). 
Compostas tanto de espinhos simples quanto de espinhos múltiplos, dipostos em número variável de fileiras, normalmente com sete fileiras, com exceção da primeira banda (Fig. 7D,E). Primeira banda de espinhos mais larga, composta anteriormente por espinhos fortes e múltiplos, e posteriormente por espinhos simples, delgados e longos (Fig. 7D); demais bandas de espinhos como na figura 7E,F.
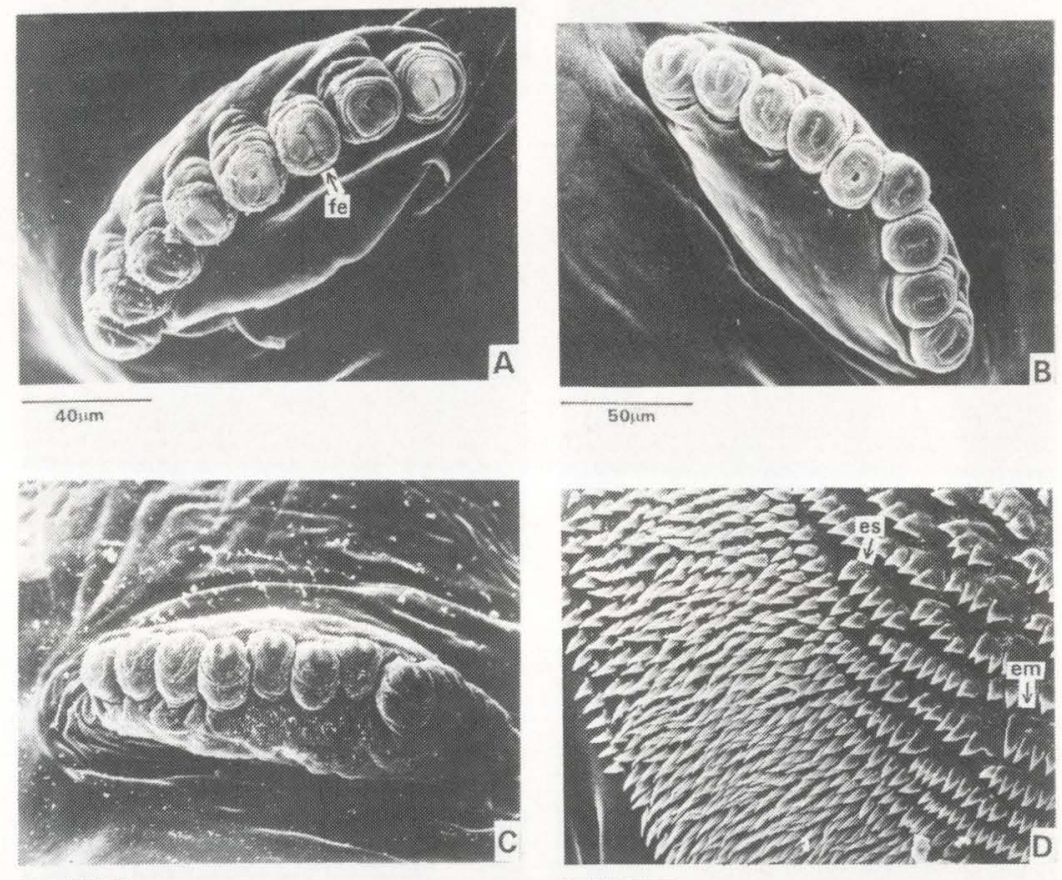

Soum

$50 \mathrm{im}$
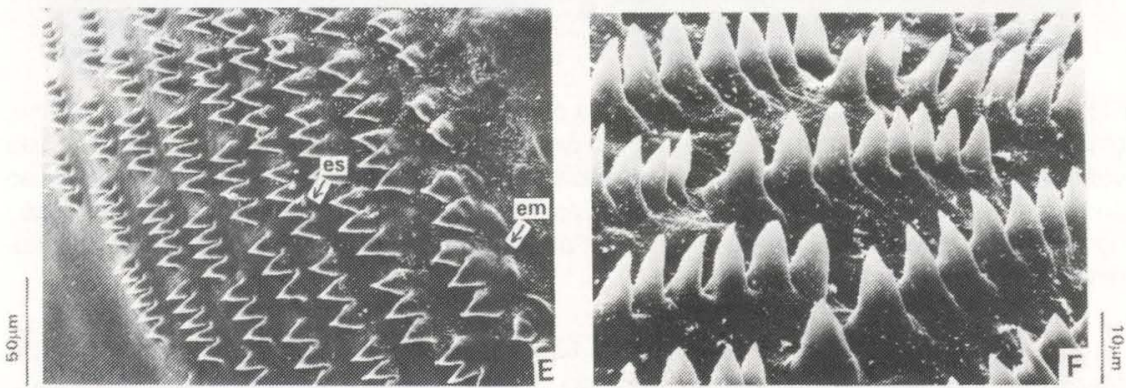

Fig. 7. Fotomicrografia de varredura de larva de terceiro instar de Sarconesia chlorogaster. (A-C) Espiráculos anteriores; (D) primeira banda de espinhos, vista lateral; (E-F) terceira banda de espinhos, vista látero-ventral. (em) Espinho múltiplo, (es) espinho simples, (fe) fenda espiracular. 
Tubérculos e processos (Figs 5G, 8A,B). Região posterior com tubérculos em igual número e posição que no segundo ínstar, porém mais proeminentes, circundando terminalmente o oitavo segmento abdominal, no centro do qual situam-se os espiráculos posteriores (Figs $5 \mathrm{G}, 8 \mathrm{~A}$ ). Placa anal bilobada, com dois tubérculos laterais (Fig. 8A,B).

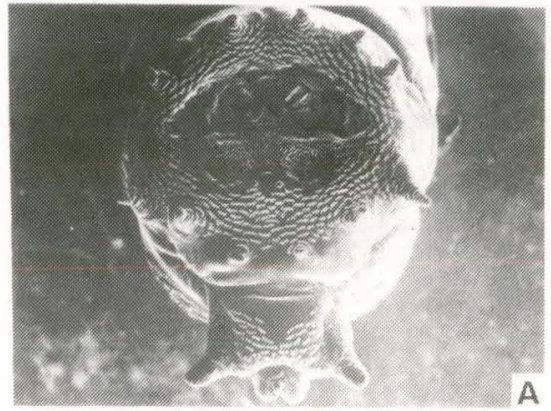

$0,5 \mathrm{~mm}$

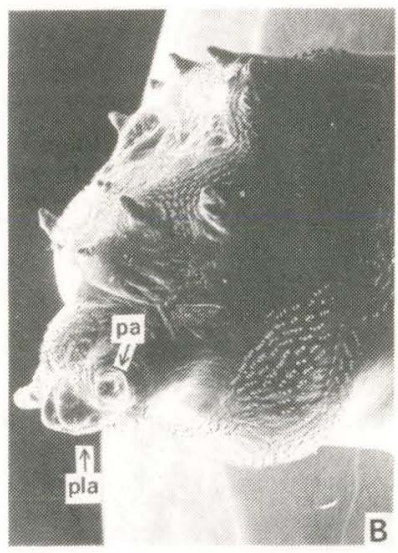

$50 \mathrm{~km}$

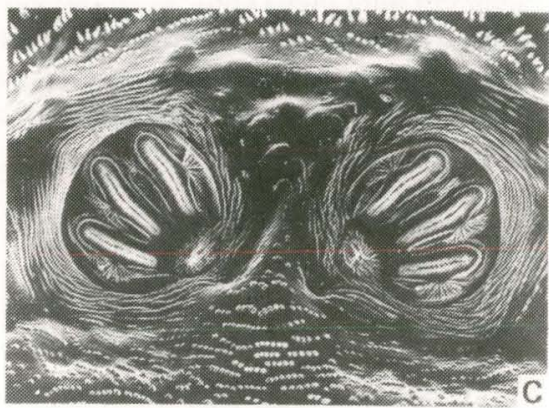

$100 \mathrm{um}$

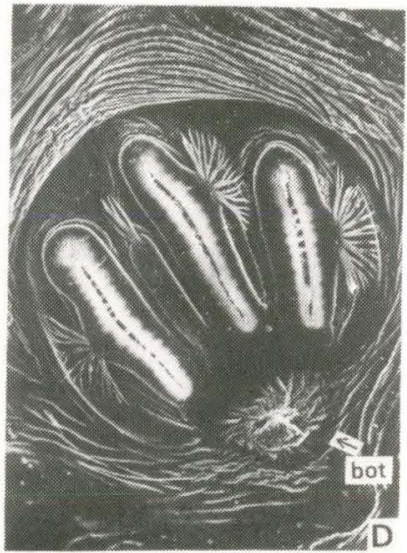

50 surs?

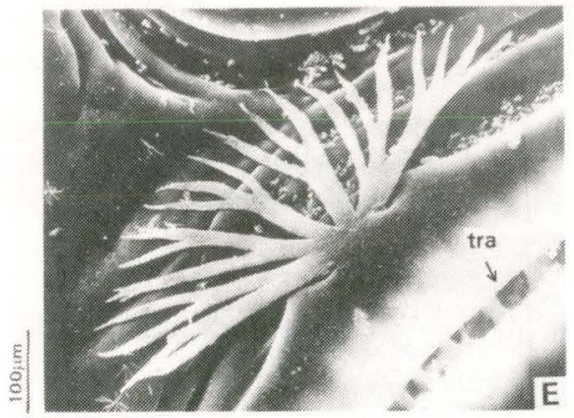

Fig. 8. Fotomicrografia de varredura de larva de terceiro instar de Sarconesia chlorogaster. (A) Região posterior, vista frontal; (B) região posterior, vista lateral; (C-E) espiráculos posteriores. (bot) Botão, (pa) papila anal, (pla) placa anal, (tra) trabéculas transversais. 
Espiráculos posteriores (Figs 5G,H, 8C-E). Um par localizado póstero-dorsalmente no oitavo segmento abdominal, fortemente esclerotinizados, com peritrema circundando incompletamente as três fendas espiraculares (Fig. $5 \mathrm{H}$ ), cada qual com somente uma abertura de glândula periespiracular, de onde partem projeções filamentosas ramificadas (Fig. 8C,D). Quarta abertura de glândula periespiracular situada em uma placa entre as fendas externa e mediana dos espiráculos (Fig. 8D). Fendas espiraculares de forma oval alongada, dispostas paralelamente entre si; interiormente com trabéculas transversais entrelaçadas (Fig. 8E). Botão localizado inferiormente logo abaixo das fendas e visível somente em microscopia de varredura (Fig. 8D).
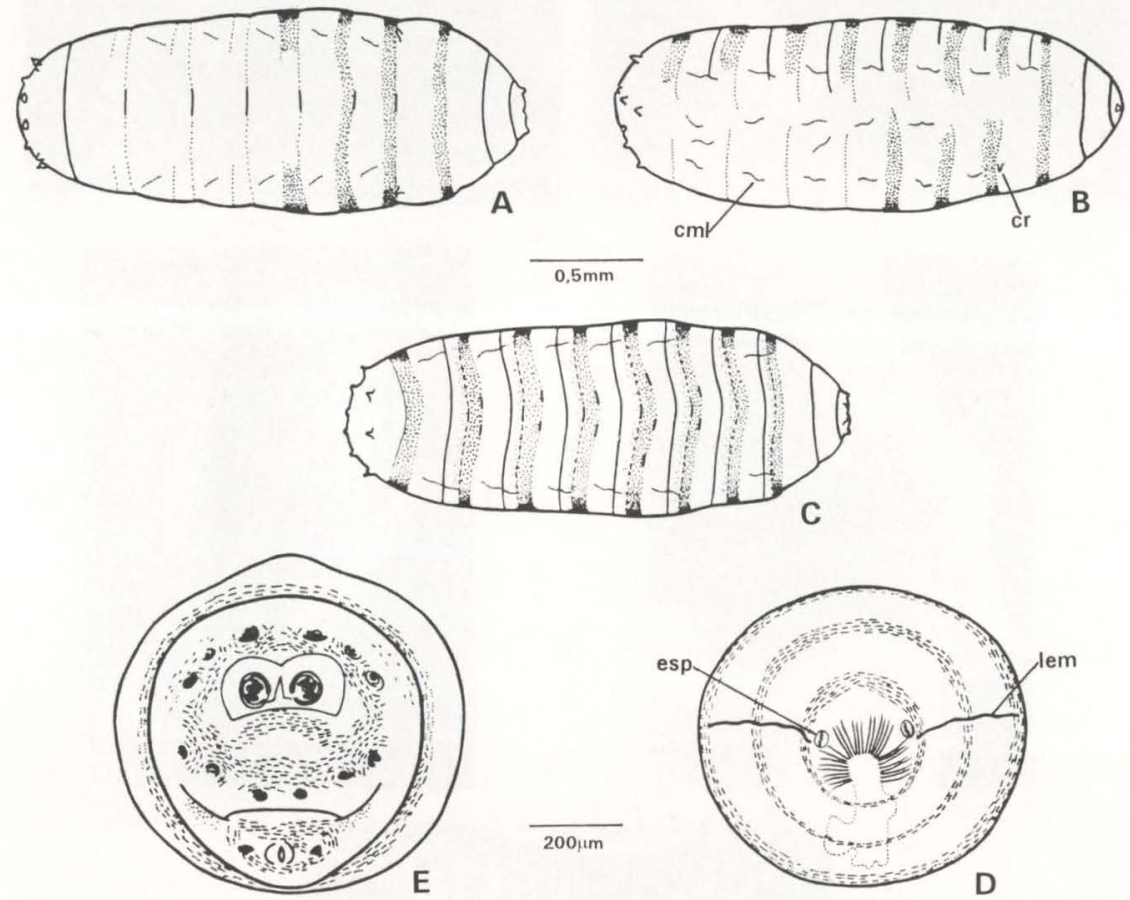

Fig. 9. Pupário de Sarconesia chlorogaster. (A) Vista dorsal; (B) vista lateral; (C) vista ventral; (D) região anterior, vista frontal; (E) região posterior, vista frontal. (cml) Cicatriz dos músculos laterais, (cr) corno respiratório, (esp) espiráculo anterior, (lem) linha de emergência.

\section{Pupário (Figs 9-11)}

Comprimento médio total $8,44 \pm 0,40 \mathrm{~mm}$, largura média (região mediana) $1,53 \pm 0,12 \mathrm{~mm}$.

Coloração geral. Marrom escuro.

Descrição. Aspecto geral figuras 9A-C, 10A-F. Pupário característico de Cyclorrhapha, em forma de barril, formado pela cutícula da larva de terceiro ínstar, totalmente esclerotinizada. Ocorre diminuição do comprimento, em relação à larva 


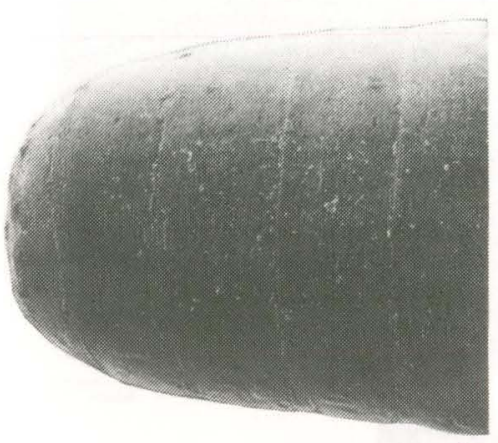

A

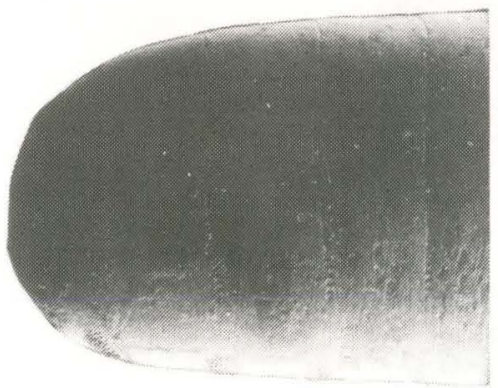

$\mathrm{C}$

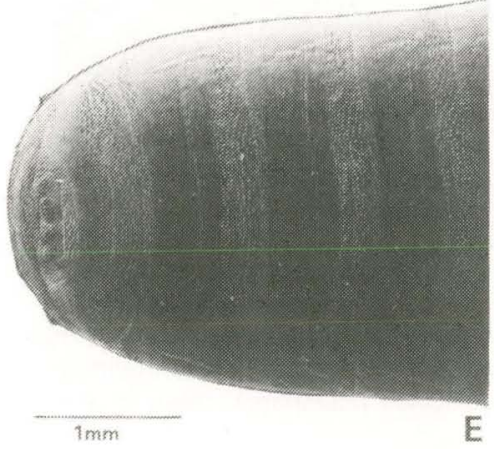

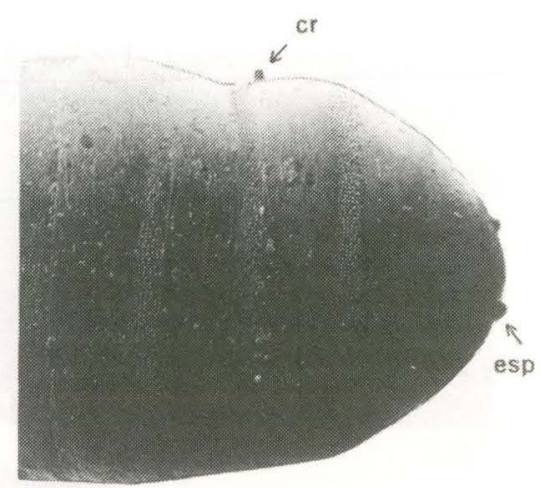

B

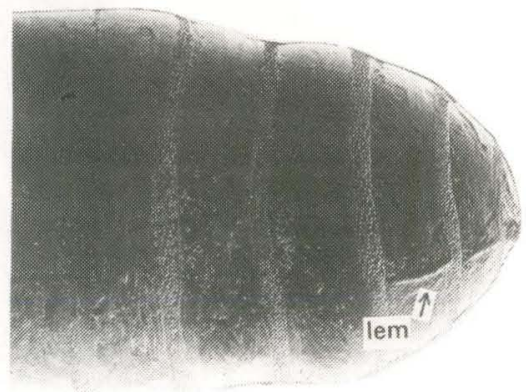

D

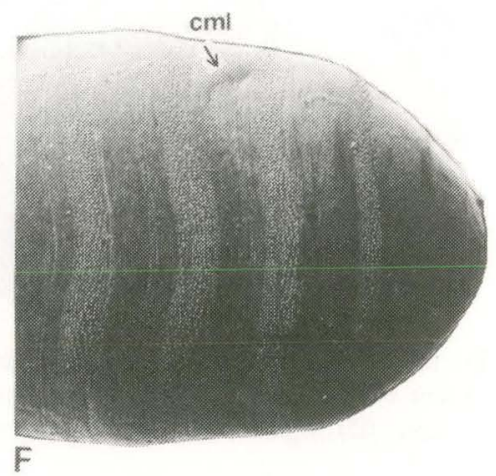

Fig. 10. Fotomicrografia do pupário de Sarconesia chlorogaster. (A) Região posterior, vista dorsal; (B) região anterior, vista dorsal; (C) região posterior, vista lateral; (D) região anterior, vista lateral; $(E)$ região posterior, vista ventral; $(F)$ região anterior, vista ventral. $(\mathbf{c m l})$ Cicatriz dos músculos laterais, (cr) corno respiratório, (esp) espiráculo anterior, (lem) linha de emergência. 

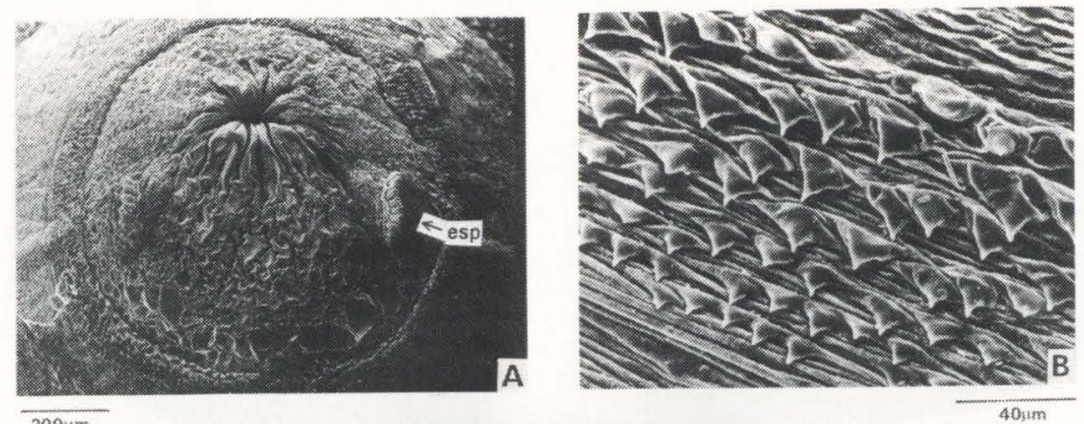

200 um
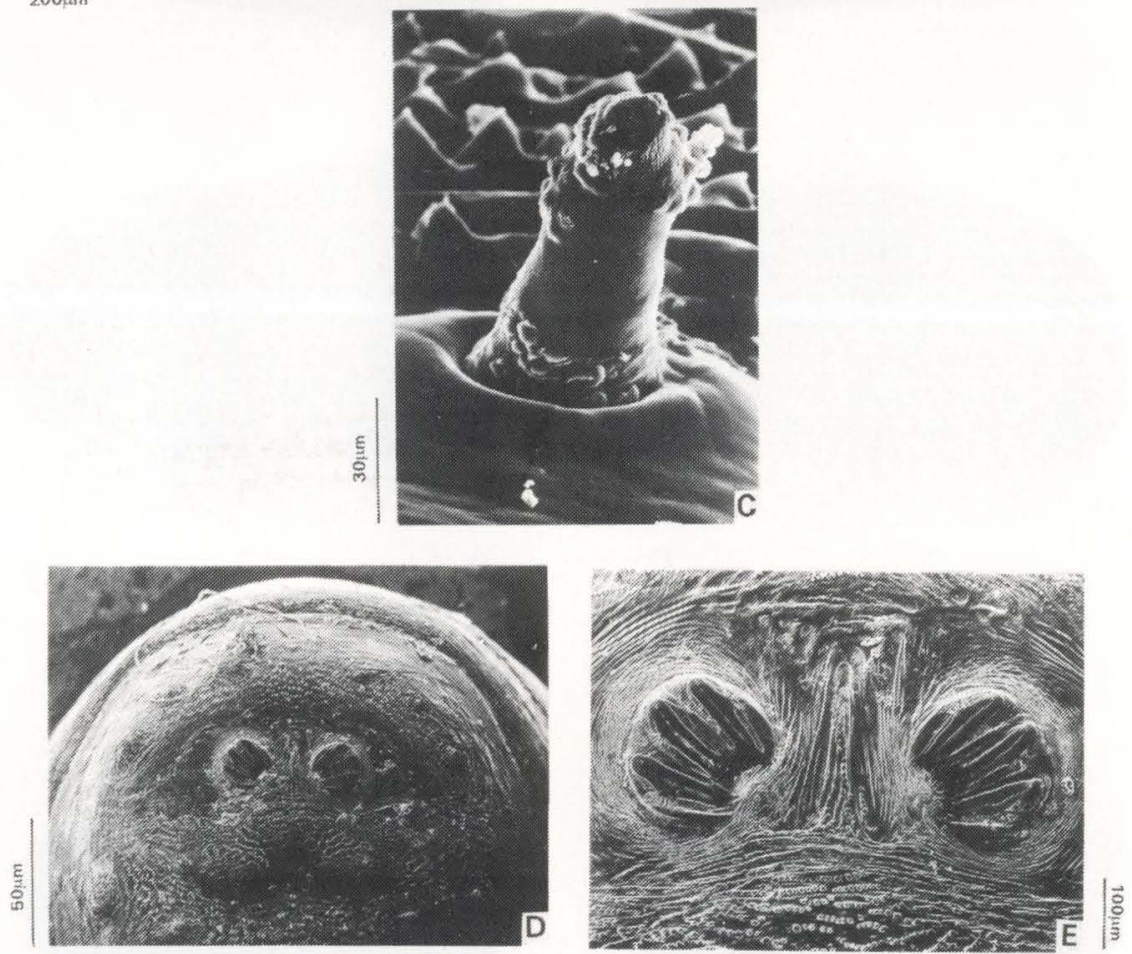

Fig. 11. Fotomicrografia de varredura do pupário de Sarconesia chlorogaster. (A) Região anterior, vista frontal; (B) terceira banda de espinhos, vista látero-ventral; (C) Corno respiratório da pupa; (D) região posterior, vista frontal; (E) espiráculos posteriores. (esp) Espiráculo anterior.

de terceiro ínstar, devido a retração total da cabeça e metade anterior do segmento protorácico (Figs 9D, 11A), e parcial retração dos demais segmentos do corpo, diminuindo o espaço entre as bandas de espinhos durante a pupariação, evidenciando "cicatrizes dos músculos laterais" (Figs 9A-C, 10F). Região anterior e posterior com a mesma largura, região mediana com a maior largura. Região anterior 
com uma linha de emergência em plano frontal, estendendo-se até o final do segmento mesotorácico, por onde se dá a emergência do adulto (Figs 9D, 10D). Leve estrangulamento radial entre o primeiro e segundo segmentos abdominais, correspondendo à cabeça da pupa (Figs 9A, 10B,D).

Espiráculos anteriores (Figs 9D, 11A). Localizados apicalmente na região anterior devido à retração da cabeça e parte do segmento protorácico.

Bandas de espinhos (Figs 9A-C, 10A-F, 11B). Com a mesma disposição que na larva de terceiro ínstar, porém, mais aproximadas devido à retração parcial do corpo. Fileiras de espinhos também mais aproximadas entre si (Fig. 11B).

Tubérculos e processos (Figs 9E, 11C-D). A exemplo de outras estruturas do corpo, os tubérculos da região posterior (Figs 9E, 11D) e da placa anal (Fig. 10E), são pouco evidentes devido a sua retração durante a pupariação, sendo visíveis somente como pequenas proeminências na superfície do pupário. Um par de cornos respiratórios de tamanho reduzido podem ser observados nas laterais posteriores do primeiro segmento abdominal (Figs 9A-B, 10B), formados por um único segmento (Fig. 11C).

Espiráculos posteriores (Figs 9E, 11D-E). Semelhantes aos de larva de terceiro ínstar, porém mais aproximados entre si devido a retração do corpo; totalmente esclerotinizados, inclusive suas fendas, provavelmente tornando-se não funcionais, sendo a respiração de responsabilidade exclusiva dos cornos respiratórios da pupa.

\section{DIscussão}

Os ovos desta espécie se enquadram no padrão morfológico, típico da família, descritos por FERRAR (1987).

A morfologia externa das larvas de $S$. chlorogaster é muito semelhante entre os diferentes ínstares desta espécie e entre as espécies do gênero. As diferenças entre as larvas das espécies de Sarconesia, se dão principalmente quanto à distribuição das bandas de espinhos e quanto à estrutura do esqueleto céfalo-faríngeo.

Os órgãos sensoriais da cabeça são freqüentemente denominados de antena e palpo maxilar (FERRAR 1987). Porém, SNODGRASS (1924) (apud FERRAR 1987) considera que estas estruturas não são homólogas às mesmas em adultos, preferindo designá-las como órgãos dorsal e ventral, respectivamente "antena" e "palpo maxilar".

Analisando-se as ilustrações dos esqueletos céfalo-faríngeos desta e de outras espécies de Sarconesia do presente trabalho com as de GREENBERG \& SZYSKA (1984), pode ser concluído que não há diferenças morfológicas entre o presente material estudado, proveniente do Brasil, com aquele estudado pelos autores citados acima, proveniente do Peru, a não ser no que diz respeito ao orifício na base dos ganchos orais das larvas de segundo e terceiro ínstares (Figs 3E, 5E), que segundo estes autores estaria presente somente na larva de terceiro ínstar de $S$. magellanica (GREENBERG \& SZYSKA 1984: 503, Fig. 85). Quando comparado com os esqueletos céfalo-faríngeos de outras espécies do gênero, $S$. chlorogaster demonstra possuir um esqueleto céfalo-faríngeo morfologicamente distinto e característico (GREENBERG \& SZYSKA 1984; MARILUIS \& AVALOS 1987). 
Acredita-se que os espiráculos anteriores estejam ausentes em larvas de primeiro ínstar de $S$. chlorogaster, porém KITCHING (1976) demonstrou que aberturas simples estão presentes em larvas deste ínstar em quatro espécies de Calliphoridae. FERRAR (1987) ressalta que estas aberturas espiraculares são praticamente indistingüíveis através de microscopia convencional, requerindo análises em microscopia eletrônica de varredura; a não ser em larvas de primeiro ínstar dos califorídeos do gênero Villeneuviella Austen, 1914 [= Rhyncomya Robineau-Desvoidy, 1830 (CROSSKEY 1980)], as quais apresentam conspícuos espiráculos anteriores.

A variação no número de projeções dos espiráculos anteriores encontrada em larvas de terceiro ínstar de $S$. chlorogaster por GREENBERG \& SZYSKA (1984) e QuEIROZ \& CARVALHO (1987) foi de oito a dez ramos digitiformes. Com os dados observados no presente estudo, amplia-se esta variação para sete a 11 e acrescenta-se que esta variação pode se dar no mesmo indivíduo e se mantém constante nos suscessivos ínstares. Assim sendo, acredita-se que este caráter seja de bđixo valor para caracterizações taxonômicas, uma vez que a variação na família é de uma a 30 ramificações (FERRAR 1987).

Quanto à distribuição das bandas de espinhos, os dados do presente estudo estão em conformidade com o apresentado em outros estudos desta natureza, realizados com esta espécie. MARILUIS \& AVALOS (1987) citam a presença de um espinho de eclosão dorsal na larva de primeiro ínstar de $S$. magellanica, o qual não é encontrado nas larvas de $S$. chlorogaster, sendo que a eclosão nesta espécie se dá nitidamente por movimentos de contração e expansão do corpo, exercendo pressão sobre o cório na região da linha de eclosão do ovo. GREENBERG \& SZYSKA (1984), em sua chave de identificação provisória para larvas de Calliphoridae do Peru, definem o gênero Sarconesia como sendo possuidor de somente espinhos simples na constituição das bandas de espinhos; e QUEIROZ \& CARVALHO (1987) caracterizam as bandas de espinhos de $S$. chlorogaster como sendo formadas exclusivamente por espinhos simples, levemente pigmentados e transparentes. Discorda-se destas caracterizações pois análises de microscopia de varredura, revelam que $S$. chlorogaster possui tanto espinhos simples quanto múltiplos (Fig. 7D,F), sendo que os espinhos, em sua maioria são bem pigmentados e poucos são transparentes.

MARILUIS \& AVALOS (1987) descrevem que o espiráculo posterior da larva de primeiro ínstar de $S$. magellanica possui duas aberturas estigmáticas, o que para $S$. chlorogaster não é verdadeiro, uma vez que a abertura destes espiráculos é simples. GREENBERG \& ZYSKA (1984) e QUEIROZ \& CARVALHO (1987) caracterizaram os espiráculos posteriores de $S$. chlorogaster pela ausência de botão e por possuir peritrema incompleto. Realmente o peritrema nesta espécie é incompleto, porém o botão pode ser visualizado a partir de larva de segundo ínstar, através de microscopia de varredura.

Devido a falhas metodológicas na preparação de ovos e larvas de primeiro e segundo ínstar, não foi realizado um estudo mais aprofundado destes a nível de microscopia eletrônica de varredura. Entretanto, há necessidade de que estudos posteriores lancem mão desta importante ferramenta, na elucidação de aspectos ainda obscuros da morfologia desta e de outras espécies de Calliphoridae. 


\section{CONCLUSÕES}

Com base nos dados obtidos no presente estudo são apresentadas as conclusões abaixo.

O ovo de Sarconesia chlorogaster possui micrópila simples, situada na porção apical anterior; o cório é translúcido e apresenta um linha de eclosão longitudinal na região dorsal do ovo.

Os espiráculos anteriores da larva de primeiro ínstar aparentemente estão ausentes. Há necessidade de estudos, a partir de microscopia de varredura, para elucidar-se aspectos obscuros da morfologia da larva deste ínstar.

O esqueleto céfalo-faríngeo desta espécie é característico, podendo auxiliar na identificação da espécie, desde que associado a outras características morfológicas da larva.

As bandas de espinhos podem ser formadas tanto por espinhos simples como por espinhos múltiplos, estes visualizados principalmente em microspia de varredura.

Os espiráculos anteriores possuem um número variável de fendas espiraculares, entre sete e 11, sendo que esta variação pode ocorrer no mesmo indivíduo.

Os espiráculos posteriores apresentam botão visível somente através de microscopia de varredura. As fendas espiraculares possuem trabéculas transversais, provavelmente controladoras da abertura e fechamento do espiráculo. Ao lado de cada fenda espiracular abre-se uma glândula periespiracular de onde partem projeções ramificadas.

O pupário apresenta um par de cornos respiratórios da pupa, evertidos durante a pupariação.

AGRADECIMENTOS. Ao Conselho Nacional de Desenvolvimento Científico e Tecnológico (CNPq) pela concessão da Bolsa de Mestrado ao autor sênior. Ao Centro de Microscopia Eletrônica da Universidade Federal do Paraná, em especial à Profa. Dra. Daura R. Eiras-Stofella e ao Prof. MSc. Robin M. Hofmeiser e às técnicas Vera Regina F. Pionteke e Matilde Machado, pelo auxílio técnico no preparo do material e pelas fotomicrografias eletrônicas de varredura. À Profa. Dra. Luciane Marinoni, Departamento de Zoologia da Universidade Federal do Paraná, pela arte final dos desenhos, revisão e discussão crítica do manuscrito.

\section{REFERÊNCIAS BIBLIOGRÁFICAS}

Baumgartner, D.L. \& B. GreenberG. 1985. Distribution and medical ecology of the blow flies (Diptera: Calliphoridae) of Peru. Ann. Entomol. Soc. Amer. 78 (5): 565-587.

BonatTo, S.R. 1995. Ciclo de vida de Sarconesia chlorogaster (Wiedemann) (Diptera, Calliphoridae, Toxotarsinae). Revta bras. Zool. 13 (3): 707-726.

Crosskey, R.W. 1980. Catalogue of the Diptera of the Afrotropical Region. London, British Museum (Natural History), 1437p.

DEAR, J.P. 1979. A revision of the Toxotarsinae (Diptera: Calliphoridae). Pap. Avulsos Dept. Zool., São Paulo, 32 (13): 145-182. 
FERRAR, P. 1987. A Guide to the Breeding Habits and Immature Stages of Diptera Cyclorrhapha. Copenhagen, E.J. Brill/Scandinavian Science Press, part 1 and 2,907p.

Ferreira, M.J. DE M. 1978. Sinantropia de dípteros muscóideos de Curitiba, Paraná. I. Calliphoridae. Revta Bras. Biol. 38 (2): 445-454.

GrEenBerG, B. \& M.L. SzYSKA. 1984. Immature stages and biology of fifteen species of Peruvian Calliphoridae (Diptera). Ann. Entomol. Soc. Amer. 77 (5): 488-517.

KITCHING, R.L. 1976. On the prothoracic spiracles of the first instar larvae of calyptrate Cyclorrhapha (Diptera). J. Aust. Entomol. Soc. 15: 233-235.

Lopes, H. DE S. \& D. DE O. Albuquerque. 1982. Notes on Neotropical Calliphoridae (Diptera). Rev. Bras. Biol. 42 (1): 63-69.

MARILUIS, J.C. \& D.S. AvALOS. 1987. Contribucion al conocimiento de los estadios del desarrollo de Sarconesiops magellanica (Le Guillou, 1842) (Diptera, Calliphoridae, Toxotarsinae). Rev. Soc. Entomol. Argent. 44 (3-4): 353-356.

Mariluis, J.C. \& S.V. Peris. 1984. Datos para una sinopsis de los Calliphoridae neotropicales. Eos - Rev. Esp. Entomol. 60: 67-86.

MELLO, R.P DE. 1972. Contribuição ao estudo do gênero Sarconesia Bigot, 1857 (Diptera: Calliphoridae). Rev. Bras. Biol. 32 (4): 533-537.

Queiroz, S.M.P.; J.R. DE Almeida; C.J.B. DE Carvalho \& L. Dudas. 1985. Bionomia de Sarconesia chlorogaster (Wiedemann, 1830) em Curitiba, Paraná, Brasil. An. Soc. Entomol. Bras. 14 (1): 105-110.

QueIROZ, S.M.P. DE \& C.J.B. DE CARVALHO. 1987. Chave pictórica e descrições de larvas de $3^{\circ}$ ínstar de Diptera (Calliphoridae, Muscidae e Fanniidae) em vazadouros de resíduos sólidos domésticos em Curitiba, Paraná. An. Soc. Entomol. Bras. 16 (2): 265-288.

SKIDMORE, P. 1985. The biology of the Muscidae of the word. Dordrecht, Dr W. Junk Publishers, XIV+550p.

Shewell, G.E. 1987. Family Calliphoridae. In: J.F. MCAlPINE; B.V. PeTERSON; G.E. Shewell; H.J. TESKEY; J.R. VOCKeroth \& D.M. WoOd (Eds). Manual of Neartic Diptera. Ottawa, Research Branch Agriculture Canada, Volume 2, VI+675-1332p.

Recebido em 08.V.1996; aceito em 08.XI.1996 